\title{
E EFFECTIVENESS OF THE PADANG PARIAMAN DISASTER EMERGENCY PREPAREDNESS PROGRAM (PAPA SADAR BANA) CALL CENTER 112 IN DISASTER MANAGEMENT IN PADANG PARIAMAN REGENCY
}

\author{
*Zikri Alhadi ${ }^{1}$, Fathiaty Mandaita ${ }^{2}$, Rahmadani Yusran ${ }^{3}$ \\ *123 Department of Public Administration- Universitas Negeri Padang, Indonesia \\ Email: zikrialhadi@gmail.com
}

*Corresponding Author, Received: March 8, 2021. Revised: March 21, 2021. Accepted: May 20, 2021

\begin{abstract}
This study discusses the importance of the role of Information Technology in dealing with disaster problems in the Padang Pariaman Regency. Public service innovation by the government that utilizes Information Technology, namely E-Government, Program (Papa Sadar Bana) Call Center 112, is expected to help the community in disasters. This study uses the Theory of Effectiveness by Primanda (2017), namely with indicators of Program Target Accuracy, Program Socialization, Program Objectives, and Monitoring to measure the effectiveness of a program. This study aims to describe and understand the program effectiveness (papa conscious call center 112) in Disaster Management in Padang Pariaman Regency. The method used in this research is qualitative research with descriptive methods - data collection techniques in this study by interview, observation, and documentation. Furthermore, the informants in this study were the Head of BPBD of Padang Pariaman Regency, secretary, Call Center Staff 112, PUSDALOPS, TRC TEAM, Head of Sub-Division for Reconstruction \& Rehabilitation and the Community.
\end{abstract}

Keywords: Disaster Management, E-Government, Preparedness

\begin{tabular}{ll}
\hline (c) (i) () This work is licensed under the Creative Commons Attribution-ShareAlike 4.0 \\
International License
\end{tabular}

\section{INTRODUCTION}

The rapid development of technology has made information spread widely to remote areas in Indonesia. Technology seems to be a basic necessity for the people of Indonesia. Therefore innovations are also increasing in the development of the world of information technology to facilitate the activities carried out by the community. The government or the private sector inevitably creates information technology that can enable their work. It seems that information technology has become one of the ways to facilitate the activities of the community, government, and the private sector in carrying out their duties and functions, including in disaster management.

This is based on Article $28 \mathrm{~F}$ of the 1945 Constitution, which reads: "Every human being has the right to convey and obtain information for personal and environmental development, and has the right to obtain, possess, seek, process, store, and convey information using all available forms of media."

According to [1] the government's role in DRR is interpreted as effective integration of disaster risk reduction considerations into sustainable development policies, plans, and programs at all levels, with particular emphasis on prevention, mitigation, and disaster vulnerability mitigation. Law number 24 of 2007 concerning disaster management states that mitigation is a series of ways to reduce the risk of a disaster or the impact of a disaster that occurs by physical development and awareness and increased capacity to face the threat of a disaster.

In increasingly sophisticated information technology, governments in developing countries compete to keep up with developments in information technology. Information technology is a basic need of society, where every community activity involves elements of technology and information. This is a significant demand for the government in serving the community so that people get optimal service. The community has a massive role in running the government process, and the community has excellent demands for public assistance to become outstanding public services.

Padang Pariaman is a regency in West Sumatra, Padang Pariaman district, including areas prone to disasters, such as landslides, earthquakes, fallen trees, coastal abrasion, floods, missing people, etc.

The Regional Disaster Management Agency (BPBD) Padang Pariaman Regency established a Papa Sadar Bana program (Padang Pariaman 
Emergency Emergency Alert) Call Center 112, which aims to provide quick assistance to the community a disaster occurs. The purpose of the Padang Pariaman Regency BPBD program is so that people whose areas are affected by the disaster can ask for quick help by simply calling the contact number 112 or going through social media owned by BPBD Padang Pariaman Regency. In this case, the target program of the BPBD of Padang Pariaman Regency is the people who live in the District of Padang Pariaman. From the above problems, the authors would like to explore and research and focus this research more to know the effectiveness of program implementation (Papa Sadar Bana call center 112) in Disaster Management in Padang Pariaman Regency.

The government should be responsible for carrying out disaster management as regulated in Law Number 24 of 2007 concerning Disaster Management. The law stipulates that those responsible for carrying out disaster management are the central government and local governments through non-departmental government institutions, i.e., National Disaster Management Agency (BNPB) for the mid-level and BPBD for the local level. With the existence of BPBD, it is expected that natural disasters occurring in the regions will be responsive to the possibility of natural disasters [1].

\section{METHODS}

This research is qualitative research with descriptive methods. [2] says qualitative research aims to study incidents regarding research subjects such as actions, motivation, behavior, actions, perceptions, and so on in a descriptive way in the form of sentences and language in an exceptional natural context by utilizing various scientific methods. The research location used in this study is located at the BPBD of Padang Pariaman Limpato Regency, Balah Aia, VII Koto Sungai Sariak, Padang Pariaman Regency, West Sumatra 25574, especially in the Call Centerfield. The reason for choosing this location is that the agency has never been used as an object of the research study.

Retrieval of data from research using interview, observation, and documentation techniques. Interviews with several employees of the Padang Pariaman District BPBD and the community. Statements were made directly down to the field to see the condition of the Papa Sadar Bana Call center 112 program flow, then capturing the moments and facilities used in running the program both in the field and in BPBD Padang Pariaman Regency itself

\section{RESULTS AND DISCUSSION}

Based on research and analysis carried out in the field, seeing the effectiveness of the program (papa conscious call center 112) in disaster management in Kabupaten Padang Pariaman is already operational but not $100 \%$ effective. Therefore, the researcher tries to provide an overview of the effectiveness of the Papa Sadar Bana awareness call center 112 programs in disaster management in Padang Pariaman Regency by using Indicator Theory as proposed by [3], namely by looking at the accuracy of program recommendations, program socialization, program objectives, and monitoring.)

\section{a. Program Target Accuracy}

The accuracy of program targets is the extent to which program innovations carried out are correct with the targets aimed at by the previous program. In this case, the accuracy of program targets is the community of the Padang Pariaman Regency area in using the Papa Sadar Bana Call Center 112 program to report related disasters that occur in the community. Based on the objectives of the Papa Sadar Bana Call Center 112 program, which is to make it easier for the people of the Padang Pariaman Regency to contact the BPBD of Padang Pariaman Regency to ask for help related to disasters that occur in that area.

Subagyo in Budiani explained that effectiveness is the similarity of output with predetermined goals [9]. The result produced by the Papa Sadar Bana Call Center 112 program is to make people aware of disasters that occur around the community, equipped with an understanding of using Call Center 112.

The effectiveness of government programs is measured using the Primanda indicator, namely program targeting accuracy. According to [4], describing the accuracy of program targets is the extent to which the program objectives are suitable following predetermined targets. In the accuracy of program targeting, there are still many problems faced, such as community anticipation, most of which do not understand the program made by the BPBD of Padang Pariaman Regency.

\section{b. Program Socialization}

According to [5], socialization is a form of conveying information in the form of a new culture to the public. When related to this research, this research means that information in the form of culture is the Papa Sadar Bana Call Center 112 program which is introduced to the 'new society' as the target of government programs. Program socialization is an activity to convey information about the socialization program to obtain information about program implementation to the general public and the program targets. 
The socialization of this research program is to show and disseminate information about the Papa Sadar Bana Call Center 112 program to the public as the target of the Papa Sadar Bana Call Center 112 program to understand thoroughly what and how is concerned about the Papa Sadar Bana Call Center 112 program.

Program socialization is an indicator formulated by Primanda as a prerequisite for knowing the effectiveness of the Papa Sadar Bana Call Center 112 program in Disaster Management in Padang Pariaman Regency. Because according to Primanda (2017), program socialization must be carried out so that the Papa Sadar Bana Call Center 112 program can be fully and thoroughly understood to the people of Padang Pariaman Regency about its activities the benefits of the program. In the indicators of the socialization of this program, various ways were found to socialize the program, such as socialization in the form of print media, social media, and direct delivery from the BPBD of Padang Pariaman Regency to the community.

\section{c. Program Objectives}

The program aims to compare the equations for the expected results of the efforts spent by the program. Program objectives are set so that program implementation is aligned with previously designed goals. The effectiveness or failure of a program's objectives is known by comparing the program objectives and the outputs produced by the program. The third program objective indicator put forward by [6] is the extent to which program implementation results match the program objectives set.

The effectiveness of the Papa Sadar Bana Call Center 112 program in disaster management in Kabupaten Padang Pariaman is seen from the extent to which the objectives of the program have been adequately achieved. If a program achieves its previously planned goals, the program can be said to be effective; conversely, if it does not reach the desired goals, then the program cannot be said to be effective.

Based on the objectives of the Papa Sadar Bana Call Center 112 program to facilitate the community in the District of Padang Pariaman to convey information related to disasters. The achievement of a program objective can be seen in how the output is obtained. To assess a program running following the goals set, we first have to know what the program objectives are being implemented. The Papa Sadar Bana Call Center 112 program aims to make it easier for the community in the District of Padang Pariaman to convey information related to disasters. This program activity is carried out during the phase of a disaster or emergency response, and it means that when a disaster occurs in an area of Padang Pariaman Regency, the community can directly contact Call Center 112 to ask for help from BPBD Padang Pariaman Regency so that the Reaction Team Fast can carry out the emergency response.

In implementing program objectives, many problems are faced, such as many people who do not understand the program and then inadequate equipment so that when a disaster occurs, more than 2 BPBD places find it difficult to distribute evacuation equipment. So that the effectiveness of the Papa Sadar Bana Call Center 112 program is still not optimal in disaster management in Padang Pariaman Regency.

\section{d. Monitoring}

The next indicator to measure the effectiveness of a program is monitoring. Monitoring is a process of gathering information after participating in program activities, whether it is running according to a predetermined plan. Monitoring is used to collect data if the program provides the desired output or vice versa. Monitoring is an essential indicator in the realization of the desired program, according to [7] theory which states that monitoring is doing something after obtaining information from the program as a public attention attractor and continues by [8-9] saying that monitoring is a process of observing, collecting, recording, processing and providing information to help make program management decisions.

The Papa Sadar Bana Call Center 112 program is effective in its implementation in disaster management in Padang Pariaman Regency. It can be seen from the program monitoring indicators, where monitoring activities are carried out through the operator running the Papa Sadar Bana Call Center 112 program or internally, monitoring the program through monitoring and evaluation. Against Call Center 112 and see the performance of the operator who runs the program. Field monitoring is carried out from the program output

\section{CONCLUSION}

The Effectiveness of the Papa Awareness Call Center 112 Program in Disaster Management in Padang Pariaman Regency. Based on the research that has been described, the authors conclude that the effectiveness of this program is not yet effective because there are still many shortcomings of the Papa Sadar Bana Call Center 112 program both internally and externally. All of this can be seen from understanding the indicators in [3] theory, namely the accuracy of program targets, program socialization, program objectives, and monitoring. 


\section{ACKNOWLEDGEMENTS}

This research can be carried out smoothly because of the help and cooperation of various parties. Therefore, the author would like to thank the Rector of Universitas Negeri Padang and the Government of Padang Pariaman Regency.

\section{REFERENCES}

[1] Alhadi, Z., Maani, K. D., Nurhabibi, P., \& Syarief, A. (2018). An analysis of the problem in composing of tsunami contingency plan in Padang City. In MATEC Web of Conferences (Vol. 229, p. 03007). EDP Sciences.

[2] Alhadi, Z., Muchtar, B., Khaidir, A., Turnip, E. S., \& Yanti, N. S. (2020) The Capability of BPBD to Reducing Disaster Risk in Padang City-Indonesia.

[3] Budiani, Ni Wayan. Jurnal Ekonomi dan Sosial, Vol.2, No.1, 2007: Efektivitas Program Penanggulangan Pengangguran Karang Taruna "Eka Taruna Bhakti" Desa Sumerta Kelod Kecamatan Denpasar Timur Kota Denpasar. Bali: Departemen Ilmu Ekonomi Universitas Udayana.

[4] Jibril, Ahmad, (2015) Efektivitas Program Perpuseru Di Perpustakan Umum Kabupaten Pamekasan. Fakultas Ilmu Sosial dan Ilmu Politik, Universitas Airlangga. Jl. Airlangga 4-6 Surabaya, 60286, Indonesia. Email: ajibril.official@gmail.com

[5] Moleong, Lexy J. 2011. Metode Penelitian Kualitatif (Edisi Revisi). Bandung: Remaja Rosdakarya

[6] Primanda Riski, 2017. Efektivitas Program SMS Gateway Pada Masyarakat Oleh Dinas Kependudukan dan Pencatatan Sipil Kabupaten Bintan, Jurnal Ilmu Administrasi Negara (JUAN), Vol. 5 No. 2, ISSN $2354-5798$.

[7] Soekartawi. 1995. Monitoring dan Evaluasi Proyek Pendidikan. Jakarta: PT Dunia Pustaka.

[8] Undang-Undang Dasar 1945 Pasal 28F Tentang Teknologi Informasi dan Komunikasi

[9] Undang-undang nomor 24 tahun 2007 tentang penanggulangan bencana. 